\title{
Italian causatives and the grammar of (in)direct causation
}

\section{As causativas do italiano e a gramática da causação (in) direta}

Marta Donazzan

\begin{abstract}
This paper tackles the relation between syntax and semantics in causative structures, and it concentrates on the empirical case offered by causative constructions in Italian. Italian exhibits two types of causative constructions (so-called faire-par and faire-infinitive constructions) that have been the subject of extensive inquiry in the literature. I argue that, in order to capture the semantic similarities and differences between the two types of syntactic constructions in Italian, it is necessary to relate their properties to the underlying causative structure that they express. This approach leads to the rejection of previous accounts that distinguish the two structural types on the basis of the selectional properties of the first causative verb. An account in terms of Voice alternation is retained, and I present new empirical evidence for this approach, drawn from comparison with other causative constructions in Italian and from the discussion of the transitive/anticausative alternation in the infinitive clause.
\end{abstract}

Keywords: semantics, causative constructions, Voice alternation

\footnotetext{
${ }^{*}$ University of Cologne
} 
M. Donazzan

Italian causatives

and the grammar

of indirect

causation

\section{Resumo}

Esse artigo discute a relação entre sintaxe e semântica em estruturas causativas e se concentra no exemplo oferecido pelas construções causativas no italiano. O italiano exibe dois tipos de construções causativas (as chamadas construções faire-par e faire-infinitivo), que têm sido o tema de uma extensa investigação na literatura. Argumento que, para capturar as similaridades e as diferenças semânticas entre esses dois tipos de construções sintáticas no italiano, é necessário relacionar suas propriedades com a estrutura causativa subjacente que elas expressam. Essa abordagem nos leva a rejeitar propostas anteriores que distinguem dois tipos estruturais com base em propriedades selecionais do primeiro verbo causativo. Uma abordagem em termos de alternância de Voz é assumida e apresento novas evidências empíricas para essa abordagem, retiradas da comparação com outras construções causativas no italiano e da discussão da alternância transitivo/anticausativo em orações infinitivas.

Palavras-chave: semântica, construções causativas, alternância de Voz 


\section{Introduction}

7 his paper tackles the issue of the semantics of causation by examining the syntactic realization of causative structures. I discuss the case of socalled syntactic causatives, i.e. causative structures that are expressed by periphrastic constructions (1). In the literature, syntactic causatives have been opposed to both lexical (synthetic) causatives (2), which arguably feature a silent causative morpheme incorporated onto the lexical verb (HALE; KAYSER, 1993; RAPPAPORT-HOVAV; LEVIN, 1998), and to morphological causatives, where causativity is encoded in a bound morpheme on the lexical predicate (BAKER, 1988).

(1) John made the kite fly.

(2) John flew the kite.

It is generally assumed that the difference between syntactic and lexical causatives can be related to the semantics of causation following a somewhat iconic principle: forms that are syntactically more complex also tend to express more complex semantic structures (GIVÓN, 1984; WOLFF, 2003). In this sense, a construction like (1) in English would express a more complex causative structure than that expressed by the lexical verb $f l y$ in (2). The relative complexity 
M. Donazzan Italian causatives and the grammar of indirect causation of (1) with respect to (2) seems intuitively plausible. We understand from (1) that the kite had its own capacity of flying, and John made an event happen, which instantiates this capacity; sentence (2), on the other hand, seems more appropriate in order to describe a situation where John was responsible for the flying of the kite, which wouldn't have occurred if he had not acted in some way. In other words, sentence (1) expresses a different type of involvement by John with respect to the event of the kite flying: the kite flies, and John does something to make this event happen. In (2), on the other hand, the event of flying the kite is put under John's direct control. In the following, I characterize the interpretive difference between (1) and (2) in terms of indirect and direct causative relations, respectively.

In its most essential form, a causative structure can be represented as a relation between two entities, one of which (the Cause) is deemed responsible for the existence of the second (the effect). In Neo-Davidsonian semantics, causative structures are formed minimally by two events (the causing sub-event e1 and the caused sub-event e2) 1 which are linked by a causative relation; the role of the Causer2 of the first event is introduced by an independent predicate (3).

$$
\text { Causer(x, e1) \& } \operatorname{CAUSE}\left(\mathrm{e}_{1}, \mathrm{e}_{2}\right)
$$

An underlying representation along the lines of the one in (3) has been related to the linguistic realization of lexical causative constructions (cf. RAPPAPORT-HOVAV; LEVIN, 1998). The causal chain in (3) seems however too simple to represent the structure of the syntactic constructions that I discuss in this paper, which, as I tried to spell out in the paraphrases of (1) and (2), describe indirect causal relations involving two controllers for the achievement of the final event. In order to represent indirect causative relation, the simple structure in (3) should therefore be expanded to include an additional event, originated by the Causer and controlled by a distinct participant. The introduction of an intermediate causative event ensures that this participant, traditionally referred to as the Causee, is ultimately directly responsible for the final event (4).

\section{Indirect causation \\ Causer(x, e1) \& CAUSE(e1,e2) \& Causee(y,e2) \& CAUSE(e2, e3).}

As it appears from the representations in (3) and (4), the main differences between direct and indirect causation concern, to start with, the introduction of 1 In the representation (3), and in the following discussion, I use the variable $e$ to represent any type of eventualities, events and states. I will specify the Aktionsart of the eventuality represented by $e$ only when it is relevant in the discussion.

2 Causer is used here as a placeholder for the Initiator of the first event (as opposed to Causee, see (4)). It is a cover term for both Agent and Cause, irrespective of animacy and other agentive properties. I discuss in sec. 2.2 the difference between distinct types of Causers (Agents, Instruments, natural forces, events etc.)
Revista Letras,

Curitiba, UFPR, n. 96, pp.398-422, jul./dez. 2017. ISSN 2236-0999 (versão eletrônica) 
$\mathrm{e}_{2}$ in the structure. Indirect causative structures are thus composed of (at least) two sub-events. Next, the structures differ for the presence of the Causee, who is the causer of the final event (i.e. $e_{3}$ in (4)). One of the questions that I address in this paper is the following: how does this complexity relate to the linguistic realization of the structure?

In this paper, I look at the direct/indirect relation concentrating on the empirical case offered by syntactic causative constructions in Italian. Besides lexical causatives (5), Italian exhibits two syntactic causative constructions, exemplified by (6) and (7) below, both meaning roughly that Mario made the janitor open the door.

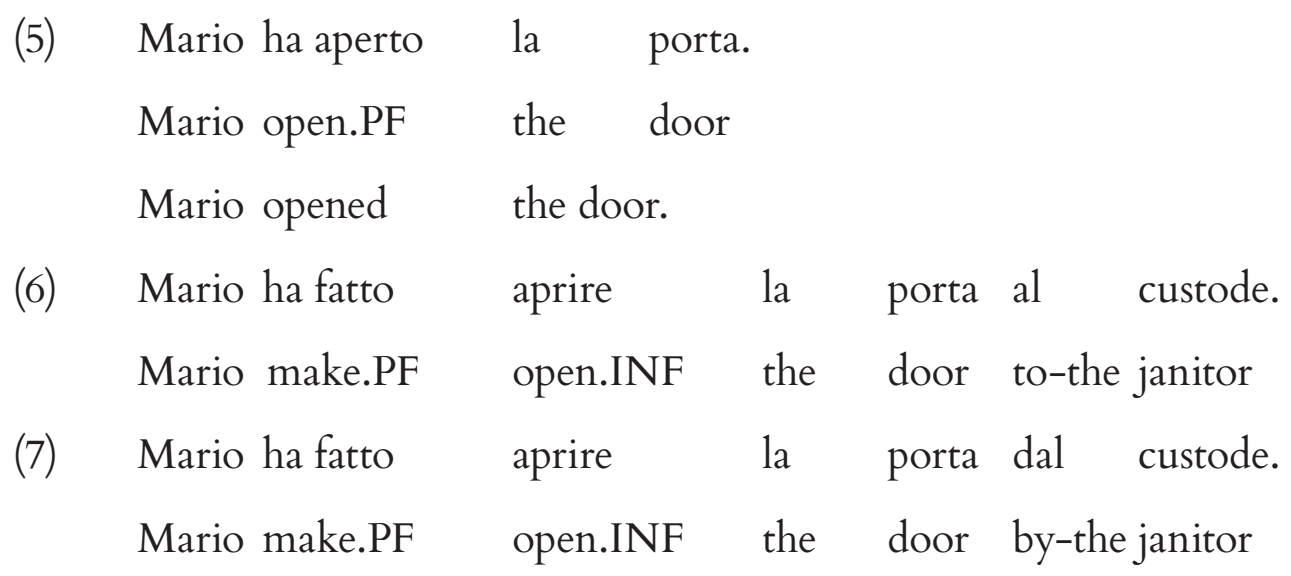
with, they can be opposed to (3) in virtue of their meaning. The lexical causative in (5) is felicitous in a situation where Mario acted directly on the door and succeeded in opening it. Sentences (6) and (7) both convey that Mario obtained the same result by controlling an intermediate event, the event of making the janitor act on the door: they express an indirect causal relation between Mario and the event described by the infinitive. In both (6) and (7), Mario is not directly controlling the event of opening the door, and sentence (5) would therefore be infelicitous if used to describe the situation expressed by (6) and (7).

As for their superficial structure, however, (6) and (7) display a difference with respect to the prepositional phrase introducing the individual that is directly responsible of the second event. In (6), the DP is introduced by the preposition a (roughly, "to"), whereas in (7) the head of the PP is the preposition da "by”. Following Kayne (1975)'s transformational analysis based on French, early works in generative syntax mapped the constructions (6) and (7) to two structural types, and called them Faire-Infinitive (FI) and Faire-Par (FP) constructions, respectively. Without committing to Kayne's analysis, I follow here this standard terminology. My main aim in this paper is to show that, in order to capture the semantic similarities and differences between the two types of causative constructions exemplified by (6) and (7), it is also necessary to 
M. Donazzan Italian causatives and the grammar of indirect causation

relate their properties to the underlying causative structure they express. This approach has not been followed by most syntactic analyses; my aim is to show its relevance for the analysis of these structures at the syntax-semantics interface.

The paper is organized as follows. In section 2, I present the main properties of Italian FI and FP constructions, relying also on the previous descriptions in the literature. In section 3, I tackle their syntactic structure focusing on the analysis recently advanced by Folli and Harley (2007). I show that Folli and Harley's analysis of the syntax and semantics of FP and FI does not lead to the correct interpretation of the structure. In particular, I argue that an approach that relies on the distinct flavours of the verbalizing head fare cannot account for the semantic distinctions observed in FP and FI. I discuss some empirical evidence against this approach, drawn from a comparison with other causative constructions in Italian and from the discussion of one additional interpretation for FP causatives. I then propose a structural account that captures most of the properties observed for FI and FP constructions. Section 4 concludes.

\section{Properties of Italian causatives}

From a syntactic point of view, causatives such as (6) and (7) have been analyzed as complex predicates and incorporated structures (see MARCANTONIO, 1981; ALSINA, 1997; GUASTI, 1996 for Italian FI/FP, inter alia). Complex predicates are formed by two or more elements that enter in a relationship of co-predication, each contributing thematic/semantic roles to a monoclausal structure (Butt, 1995). In a syntactic perspective, complex predicate formation may be described as a restructuring phenomenon and it can be targeted by language-specific tests, such as clitic climbing and long object movement in Romance (cf. RIZZI, 1976; MANZINI, 1983; ROSEN, 1989; inter alia). On the semantic side, complex predicate formation can be addressed specifically as the composition of two or more events. The issues to be addressed are then the following: (i) is there evidence that a syntactic causative realizes two events? (ii) how does the semantic structure relate to the syntactic realization of Causer and Causee?

In this section, I present some arguments supporting the hypothesis of a mapping between the underlying semantic structure in (4) and the syntax of constructions (6) and (7) in Italian. In 2.1, I present evidence for the existence of two or more events in the construction. In 2.2, I then introduce the issue of the realization of Cause and Causee, which has been a central concern in previous analyses. I briefly review and comment the main empirical observations produced by the literature about the semantic and thematic roles attributed to the event participants that instantiate these roles.

\subsection{Indirect causation and multiple events}

Revista Letras,

Curitiba, UFPR, n. 96 , pp.398-422,

jul./dez. 2017. ISSN 2236-0999 (versão eletrônica) 
Looking at the interpretation of modifiers, Guasti (1996) notes that in Italian the two syntactic causatives exemplified by (6) and (7) are multi-eventive constructions, where each predicate (the light-verb fare and the infinitive) contributes one or more sub-events to the overall predication. Below I reproduce Guasti's main argument with an example that parallels the ones proposed in (6).

(8) Mario ha fatto aprire la porta al custode con una pistola

Mario make.PF open.INF the door to-the janitor with a gun

Mario made the janitor open the door with a gun.

a. Mario used a gun to make the janitor open the door

b. Mario made the janitor use a gun to open the door

In sentences such as (8), notes Guasti, the modifier PP in the final position of the sentence can be interpreted in two ways. On the first reading, paraphrased by (8a), the PP introduces the instrument that Mario used to act on the janitor in order to realize the second event; on the second reading (8b), the PP introduces the instrument with which the janitor acted on the door, in order to open it. In structural terms, the PP "with a gun" in (8) may modify either the first causative event $\mathrm{e} 1$ or the second causative event $\mathrm{e} 2$ in the representation (7). Instrument PPs thus provide evidence for the accessibility of at least two events in the causative construction. In order to target the third event e 3 introduced by the second causative relation of (7), we must access the sub-lexical structure of the verb open. What (7) says is that the janitor acted on the door, and as a result he produced the state of the door being open. In this case instrument or manner modifiers are not very helpful: since $\mathrm{e} 3$ is not a dynamic event, it cannot be modified by an instrument or manner adverbial. However, the subevent structure of causative lexical verbs can be targeted by iterative adverbials like English again, or its Italian counterpart di nuovo in (9), which may iterate stative predicates as well (see VON STECHOW, 1996, among others).

(9) Mario ha fatto aprire la porta al custode di nuovo.

Mario make.PF open.INF the door to-the janitor again.

a. [Mario had made the janitor open the door in the morning, but when he came back from the meeting the door had been locked. Then...]

b. [The janitor had opened the door in the morning, but then someone locked it again. Then...]

c. [Mario had opened the door in the morning, and then he lost his keys. When he came back from the meeting the door was locked. Then...] 
M. Donazzan Italian causatives and the grammar of indirect causation

The sentence-final modifier di nuovo "again" in (9) is three-way ambiguous. It shares two of its possible adjunction sites with those of manner adverbials: di nuovo can iterate the event of Mario acting on the janitor (9a) or that of the janitor acting on the door (9b). However, di nuovo can also iterate the event of the door being opened, which is the only possible interpretation in the context provided by (9c). This reading, called "restitutive" in the literature, provides evidence for the accessibility of the third event e 3 when the lexical verb itself expresses a causative relation, as in (4). ${ }^{3}$

\subsection{The Causer and the Causee}

A relation of co-predication implies that two predicates both contribute thematic roles to the same argument positions. In the framework of early generative grammar, complex predicates seriously challenged the hypothesis of the Uniformity of Theta-role Assignment (BAKER, 1988), and it has been of great concern for syntacticians to characterize the composition of complex predicates in terms of theta-roles and Case assignment. Complex predicates are also an ideal ground for investigating theta-role assignment from a typological perspective, with the aim of determining how thematic roles should be decomposed or ranked in terms of semantic features or entailments (DOWTY, 1991; KULIKOV et al., 2006). Consequently, whatever their theoretical background, previous analyses of FI and FP constructions generally offer detailed descriptions of the thematic constraints imposed on the argument positions occupied by the participants of the event. In this section, I review the most relevant data from the literature, and provide new empirical observations as well.

\subsubsection{Agentivity constraints on Causer and Causee}

The distinction between FP and FI causatives in Italian has been formulated as a constraint on the semantic roles of the Causer and the Causee (KAYNE, 1975; MARCANTONIO, 1981; inter alia), which is built upon the broad notion of agentivity. The generalisation is that the Causer in FI can be more or less agentive, but the Causer in FP must be agentive (10a vs. 10b).

3 The two readings in (9a) and (9b) are disambiguated if the modifier stays in its base position after the targeted predicate, as in (i) [=9a] and (ii) [=9b]. The sentence-final position is however the only available one for the restitutive interpretation.

(i) Mario ha fatto [di nuovo] aprire la porta al custode. Mario make.PF again open the door to-the janitor

(ii) Mario ha fatto aprire [di nuovo] la porta al custode. Mario make.PF open again the door to-the janitor

Revista Letras,

Curitiba, UFPR, n. 96 , pp.398-422,

jul./dez. 2017. ISSN 2236-0999 (versão eletrônica) 
(10) a. La crisi ha fatto vendere la terra ai $/^{\star}$ dai contadini $\left(\mathrm{FI} /{ }^{\star} \mathrm{FP}\right)$

The crisis make.PF sell.INF the land $\quad a /{ }^{\star} d a-D E T$ farmers

The crisis made the farmers sell their land.

b. Il padrone ha fatto vendere la terra all'/dall' amministratore. (FI/FP)

The proprietor make.PF sell.INF the land a/da-DET administrator

The proprietor made the administrator sell the land.

Conversely, the Causee of FP can be agentive or not, but the Causee of FI must be agentive (11a vs. $11 \mathrm{~b}) .^{4}$

(11) a. I pescatori hanno fatto spingere le barche a riva *alla/dalla marea.

$\left({ }^{\star} \mathrm{FI} / \mathrm{FP}\right)$

The fishermen make.PF pull.INF the boats to shore *a da-DET tide The fishermen let the tide pull the boats ashore.

b. I pescatori hanno fatto spingere le barche a riva alle/dalle donne.

The fishermen make.PF pull the boats to shore a/da-DET women

The fishermen made the women pull the boats ashore.

These empirical generalizations have been proved problematic in the literature. Their inadequacy is due to the fact that it is unclear how agentivity is characterized in the first place. The (unproblematic) examples above targeted the most prototypical cases, where non-agentive participants are represented by natural forces (that are inanimate and non-volitional) and agentive participants by human beings (animate and volitional). If one considers agentive properties, however, neither animacy nor volitionality are relevant for characterizing the Causee of FI (12)-(14). ${ }^{5}$ Looking more closely at the role of the entities that act as Causee, it seems rather that the minimal characterization of an agentive Causee should be in terms of being capable of producing the event autonomously and

4 Note that English does not seem to lexicalize the same light-verb in (11a) and (b); "let" is more appropriate than "make" in (11a).

5 In order to help the reader, I tagged the examples with respect to the lack of animacy of the Causee and of volitionality and teleological capability in relation to the event denoted by the infinitive. These descriptive tags are not meant as privative values in a system of features. 
M. Donazzan Italian causatives and the grammar of indirect causation in a predictable way (cf. the notion of "teleological capability" by Folli and Harley (2008)).

(12) I battellierifanno tirare la chiatta dai/ai buoi [-vol] The boatmen make.PF pull.INF the boat da/a-DET oxen The boatmen made the oxen pull the barge.

(13) Ho fatto analizzare i dati dal/al computer. [-anim-vol] make.PF analyze.INF the data da/a-DET computer I made the computer analyze the data.

(14) I taglialegna provocano una frana e fanno trascinare giù the lumberjacks provoke a slide and make.PF drag.INF down i tronch dal $/{ }^{\star}$ al fango. [- anim,-vol,-tel] the trunks $\mathrm{da} /{ }^{\star} \mathrm{a}-\mathrm{DET} \quad \mathrm{mud}$ The lumberjacks provoke a landslide and let the mud drag the trunks downhill.

The constraints on agentivity, in terms of prototypical entailments, appear to be stronger for the role of Causer. The attribution of an intent to the Causer in FP seems to be mandatory for the felicity of the construction. Thus, the intuition is that (15) is acceptable and (16) is not because the whole event in (15) is more plausibly interpreted as volitional, as the felicity of the purposive clause shows.

(15) La leonessa ha fatto accerchiare l'impala ai/dai giovani maschi the lioness make.PF surround.INF the-impala a/da.DET young male (per guadagnare tempo)

to gain time

The lioness made the young males surround the impala (in order to gain some time). 
(16) Il computer ha fatto eseguire la pulizia all'/*dall' antivirus

The computer make.PF execute.PF the cleaning $a /{ }^{\star} d a-D E T$ antivirus

(\#per guadagnare tempo)

to gain time

The computer made the antivirus execute the cleaning (\#in order to

gain some time).

Table 1 resumes the empirical survey. Taking agentivity at its stronger value (i.e. as implying volition, cf. (15) and (16)), one can detect an asymmetry between FP and FI concerning the realization of Causer and Causee in terms of agentive properties: the agentivity constraint is imposed on the the Causee of FI, and on the Causer of FP.

\begin{tabular}{|l|l|l|l|}
\hline & Causer & Causee & Examples \\
\hline FI & + Agent/- Agent & + Agent & $(10 \mathrm{a}, \mathrm{b}) /(11 \mathrm{a})$ \\
\hline FP & + Agent & - Agent/+Agent & $(10 \mathrm{a}) /(11 \mathrm{a}, \mathrm{b})$ \\
\hline
\end{tabular}

Table 1 Agentivity in FI and FP constructions

The data presented so far suggested different interpretations and implementations. In section 3 I discuss in particular the analysis proposed by Folli and Harley (2007), by which agentivity constraints are expressed as semantic features of the inflected verb. According to this proposal, the Italian verb fare in (6) and (7) realizes two distinct verbal heads, which distribute different semantic roles to their external argument. At first sight, this proposal yields a descriptively adequate result (modulo the qualifications concerning agentivity entailments). On the theoretical side, however, it does not answer the question raised by an interface analysis along the lines of the one that I propose here: what is the impact of these agentive constraints on the realization of a causative relation?

\subsubsection{Overt expression of the Causee}

At the descriptive level, most analyses of FP and FI agree in detecting a further interpretive difference between the two constructions, which is sometimes termed the "obligation effect". The intuition is that an FI construction is more appropriate to describe a situation where the Causer forces the realization of the event on the Causee. As the English paraphrases attempt to show, (17a) suggests that the professor imposed the reading of the book to the students, while (17b) is neutral in this respect. 
M. Donazzan Italian causatives and the grammar of indirect causation

(17) a. Il professore ha fatto leggere il suo libro agli studenti. the professor make.PF read.INF the his book a-DET students The professor made the students read his book.

b. Il professore ha fatto leggere il suo libro dagli studenti. the professor make.PF read.INF the his book a-DET students The professor had his book read by the students.

It is difficult to find a context that could show this interpretive nuance in an uncontroversial way. Guasti (1996) proposes however an indirect argument, which is based on her analysis of complex predication. Guasti (1996) relates the obligation effect to the fact that in FI the Causee receives a (Benefactive) thematic role from the inflected verb. As a consequence, her analysis also predicts that the Causee, being theta-marked by fare, must be obligatory expressed in FI causatives. The obligation effect correlates then with the mandatory realization of the Causee. To support her analysis, Guasti provides an argument drawn from the idiomatic interpretation of verb phrases, such as the VP prendere la medicina in (18). Guasti (1996) notes that, in the FI expressed by (18a), the VP may have an idiomatic interpretation, where the verb prendere is understood as "ingest"; conversely, in the FP in (18b), the verb has only the (arguably basic) meaning of "take hold". Crucially, she notes, when the Causee is implicit only the basic meaning of (18b) is accessible, showing that the structure in (18c) can only be interpreted as a FP.

(18) a. La maestra ha fatto prendere la medicina al bambino the teacher make.PF take.INF the medicine a-DEF child The teacher made the child ingest the medicine.

b. La maestra ha fatto prendere la medicina dal bambino the teacher make.PF take.INF the medicine da-DEF child The teacher made the child take hold of the medicine.

c. La maestra ha fatto prendere la medicina the teacher make.PF take.INF the medicine ${ }^{\star}(\mathrm{a}),{ }^{\vee}(\mathrm{b})$

If one accepts this argument together with the generalization depicted in Table 1, however, it is easy to find counterexamples. In the sentences below, the Causer is expressed by an event, and is therefore non-agentive; in virtue of the

Revista Letras,

Curitiba, UFPR, n. 96 , pp.398-422, jul./dez. 2017. ISSN 2236-0999 (versão eletrônica) 
generalization on agentivity in Table 1, the construction should be a FI $(19,20)$. However, in all cases the Causee can be easily left implicit.

(19) La vittoria della Nazionale ha fatto vendere tante bandiere the victory of-the national team make.PF sell.INF many flags [ agli/ *dagli ambulanti] a-DEF *da-DEF peddlers

(The victory of the national team had the peddlers sell many flags.)

(20) La situazione di emergenza ha fatto eleggere una commissione provvisoria the situation of emergency make.PF elect.INF a commission temporary

$$
\begin{array}{ll}
\text { [al } /{ }^{\star} \mathrm{dal} & \text { parlamento }] \\
\mathrm{a}-\mathrm{DEF} /{ }^{\star} \mathrm{da}-\mathrm{DEF} & \text { parliament }
\end{array}
$$

The emergency made the parliament elect a temporary commission.

\subsubsection{Summing up}

In this section, I have shown that syntactic causatives realize multieventive causative structures, and that the constraints imposed on the thematic roles attributed to the Causer and Causee should be relativized to a nuanced notion of agentivity. I have also pointed out the challenges that empirical data impose on previous analyses, in particular on the proposal by Guasti (1996). In the next section, I discuss in more details the proposal by Folli and Harley (2007), who account for the observed differences between FP and FI by assuming different semantic values for the verb fare. I show that this solution, as it is offered by Folli and Harley (2007), is also descriptively inadequate.

\section{Mapping causation in syntax: towards an account}

\subsection{Previous analyses: flavours of $v$}

Folli and Harley (2007) tackle the issues outlined in section 2.2 in a constructionist framework that follows Harley (1995)'s proposal of assigning 
M. Donazzan Italian causatives and the grammar of indirect causation semantic content to verbalizing heads. They argue that the verbal head fare in FI and FP constructions is assigned different semantic "flavours" that determine its selectional properties and the interpretation of the structure. The difference between FP and FI causatives is reduced to a selectional restriction. The relevant generalization (FOLLI; HARLEY, 2007, p. 212) is that:

a) in FI, fare is a light verb; it is the spell out of a verbalizing head endowed with a causative feature $\left(v_{C A U S E}\right)$. According to Folli and Harley, causative verbs can have agentive or non-agentive external arguments, and they can only select for a clausal complement, i.e. a vP;

b) in FP, fare is a lexical verb; it incorporates a verbalizing head $\left(v_{D O}\right)$ that can only select for an agentive subject. Lexical fare has no restriction as for the category of its complement; in order to capture the optionality in the expression of the Causee and the choice of a different preposition, Folli and Harley assume that in FP causatives $v_{D O}$ combines with a nominal argument, i.e. a nominalized VP.

\begin{tabular}{|l|l|l|l|}
\hline & $v$-head & Causer & Complement \\
\hline FI & ${ }^{v}$ CAUSE & + Agent/-Agent & vP \\
\hline FP & ${ }^{n}$ DO & + Agent & VPNOM \\
\hline
\end{tabular}

Table 2 - Folli and Harley (2007)'s proposal

The authors do not make an explicit claim concerning the semantic role of the Causee, but in terms of selectional properties of $\mathrm{v}$ their proposal captures the agentivity constraints on the Causer in Table 1 . The point where the generalization fails, as I will show, is in its imposing constraints on the complement of v. Let's start by considering the realization of the FI, following Folli and Harley's proposal. Since fare embeds a vP, in (21) the whole thematic structure of the lexical verb aprire "open" is present; the Causee is base-generated as Spec of vP on its right, and assigned dative case, which is realized by the preposition a in Italian. 
(21)

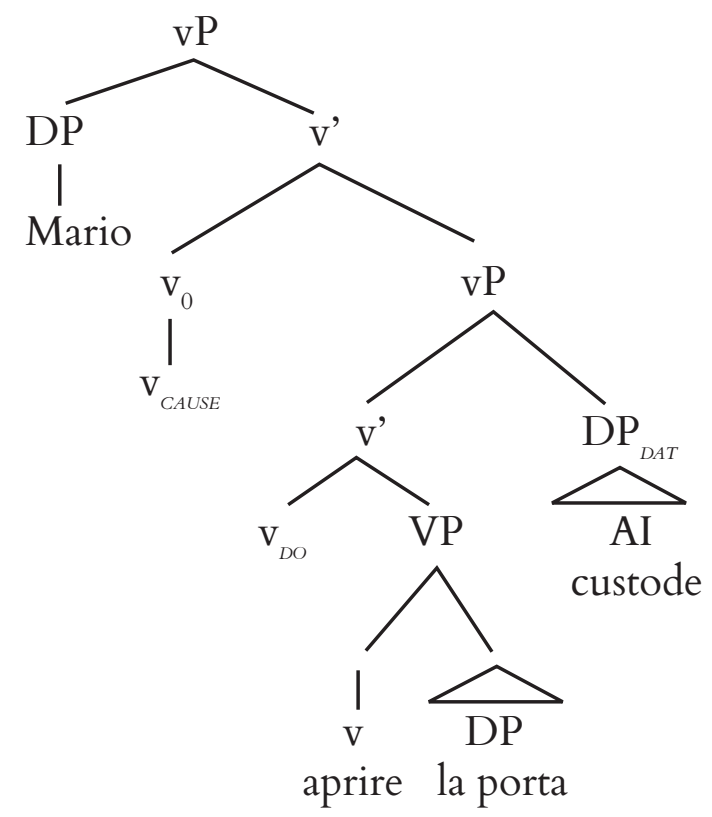

In FP causatives, on the other hand, the verb fare embeds a nominal complement, i.e. a nominalized infinitive VP (22). Being nominalized, the VP has no external argument position: the only controller of the event denoted by the VP is Mario. The Causee is an adjunct PP, optionally introduced by the preposition $d a$ (by).

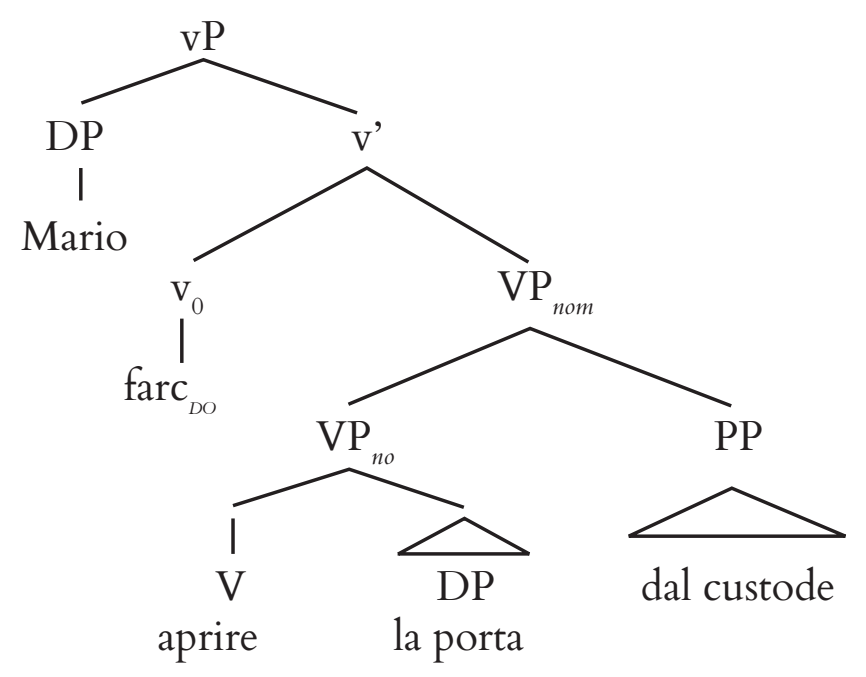

The claim that FP differ from FI as for the category of the embedded complement has one important consequence. According to this analysis, the embedded event of FI, realized by a complex vP, has its own External Argument that receives dative case from the verb; the nominalization embedded under FP, on the contrary, is "structurally agentless" (FOLLI; HARLEY, 2007, p. 216). On the theoretical side, then, Folli and Harley (2007) make a claim concerning the syntax-semantics interface. FI and FP relate differently to the semantic structure in (4): in the FI in (21), the Causee is realized as the external argument of v, whereas in (22), by assumption, it is suppressed in the syntactic realization of the causative structure. This means that either the syntactic realization of the 
M. Donazzan Italian causatives and the grammar of indirect causation

Causee has no impact for the interpretation of the construction, or the two causatives are predicted to display an interpretive difference also in terms of the causative relation they represent. In the following section, I show that neither of the two options is valuable.

\subsection{1 (In)direct causation and clausal structure}

The analysis by Folli and Harley (2007) does not make the correct empirical predictions if one considers the interpretation of the causative structures realized by FP and FI. A first argument comes from the referential accessibility of the participant acting as the Causee. As shown in section 3, in FP (and arguably also in FI) the Causee can be left implicit. When left implicit, the Causee in FP is interpreted in an arbitrary way, but it must be referentially disjoint from the subject of fare. The sentence (23) cannot mean that Mario is also the one who waters the flowers.

\section{(23) Mario ha fatto innaffiare i fiori. \\ Mario make.PF water.INF the flowers}

The constraint upon the interpretation of the Causee challenges the hypothesis that the inflected verb embeds an agentless VP, since in that case it should be possible for the Causee to receive a totally arbitrary interpretation, and the ban on coidentification with the Causer wouldn't be expected. It is telling in this respect to compare FP to predicative structures where the causative verb embeds an uncontroversial nominal constituent, as in (24) and (25). The sentences (24) and (25) display two event nouns, respectively an underived event noun and a nominalization marked by the suffix -ata (GAETA, 2002; DONAZZAN; TOVENA, in press, inter alia). In both cases, the sentences can only mean that Mario did the sleeping/swimming himself. The Causee of the event denoted by an event noun is necessarily interpreted as co-referential with the subject of fare.

(24) Mario ha fatto

un/l'errore *a $/^{\star} \mathrm{da}$ Gianni/ ${ }^{\circ K}$ di Gianni

Mario make.PS a/the mistake to/by/of Gianni

(ONLY: Mario made a mistake similar to one of Gianni’s.

(25) Mario ha fatto una/la nuotata * (a/da Gianni/di Gianni)

Mario makePF a swim.EN (`by/of Gianni)

This interpretive difference is related to the complexity of the underlying causal chain. Contrary to (24) and (25), the interpretation of (23) qualifies FP as

Revista Letras,

Curitiba, UFPR, n. 96 , pp.398-422,

jul./dez. 2017. ISSN 2236-0999 (versão eletrônica) 
always expressing indirect causation; in this sense, FP are similar to FI structures; they do not embed a nominalized constituent.

Further evidence for assuming a clausal structure in the infinitive of FP causatives is discussed by Donazzan (2017), and comes from constructions embedding transitive verbs that may undergo the transitive/anticausative alternation, such as aprire "open" in (26). Besides the interpretation by which Mario had someone else (e.g. the janitor) opening the door (26b), predicted by (22), sentence (26a) has a second plausible interpretation in terms of indirect causation. In this case, for the sentence to be felicitous, the opening is generally understood as mediated by another event (e.g. a kicking event by Mario (26c), cf. VECCHIATO, 2011), although crucially not by an intervening Causee with Agentive properties.

(26) a. Mario ha fatto aprire la porta.

Mario make.PF open.INF the door

b. Mario ha fatto aprire la porta dal custode

Mario make.PF open.INF the door by-the janitor

c. Mario ha fatto aprire la porta con un calcio/dandogli un calcio

Mario make.PF open.INF the door with a kick/giving a kick

Donazzan (2017) argues that the interpretation of (26c) can be explained if one assumes that the infinitive in (26c) is the anticausative alternant of (26b). First, the interpretation (26c) is consistently not available for transitive verbs that do not undergo the transitive/anticausative alternation and that arguably do not retain a CAUSE component in their lexical decomposition, such as innaffiare "water" (27). Second, in the anticausative version (26c) the causing source (the kick event) is not expressed by the preposition da "by" that introduces the Causee in (26a), but rather by the preposition con "with", as in matrix anticausatives.

(27) Mario ha fatto innaffiare i fiori (dal giardiniere/ \#gettando acqua in giardino)

Mario make.PF water the flowers (by the gardener/\#by throwing water in the garden) 
M. Donazzan Italian causatives and the grammar of indirect causation

\subsubsection{Summing up}

In sections 3.1, I have shown that a Cause component, and a position for the Causee, are available in both FI and FP, and I have provided evidence for a clausal structure in the infinitive of both FP and FI. The hypothesis that the infinitive in FP also realizes a complex clausal structure, allowing for a VoiceP projection, goes against the assumption, held by Folli and Harley (2007), that in FP fare is a $v_{\mathrm{DO}}$ that embeds a nominalized $\mathrm{VP}^{6}$. As a consequence, the difference between FP and FI stated in Table 2 has to be reviewed, and the reason for assuming a $v_{\mathrm{DO}}$ would be dictated only by the constraint on the selection of an agentive external argument. In the next section, I try to give an alternative account for this thematic constraint on the Causer, which attempts to reconcile the analysis of FP and FI with the (arguably more plausible) hypothesis that the first causative event is always realized by a causative verb. I suggest that the differences and similarities between FP and FI can be accounted for assuming that the embedded infinitive clause undergoes a structural alternation, which is mirrored (if not motivated) by the thematic constraints discussed in section 2 .

\subsection{Embedding causation}

\subsubsection{Alternations in embedded clauses}

In agreement with previous literature, we assume for FI causatives the structure represented in $(28 \mathrm{a}, \mathrm{b})$, where the causative verb in CauseP1 embeds a full vP (CauseP2) with its own external argument position for the Causee.

$$
\text { Mario ha fatto aprire la porta a Giulia. }
$$

a. $\quad[A g P$ Mario $[v P$ fare [ $A g P$ Giulia [ $v P$ CAUSE [ $V P$ open the door $]]]]]$

b. $\quad \exists e 1 \exists e 2 \exists e 3$.Causer(e1,Mario) \& CAUSE(e1,e2) \& Causer(e2,Giulia) \& CAUSE(e2,e3) \& open(e3) \& Theme((e3,the.door)

Revista Letras,

Curitiba, UFPR, n. 96 , pp.398-422, jul./dez. 2017. ISSN 2236-0999 (versão eletrônica)
6 Note that this empirical fact about FP does not undermine the general theory advocated by Folli and Harley (2007), since it admits that agentive $v$ s may select for full vPs. The ban on a clausal complement is however incorrect for FP in Italian, and therefore all the more unsuitable for describing the specific properties of these constructions. 

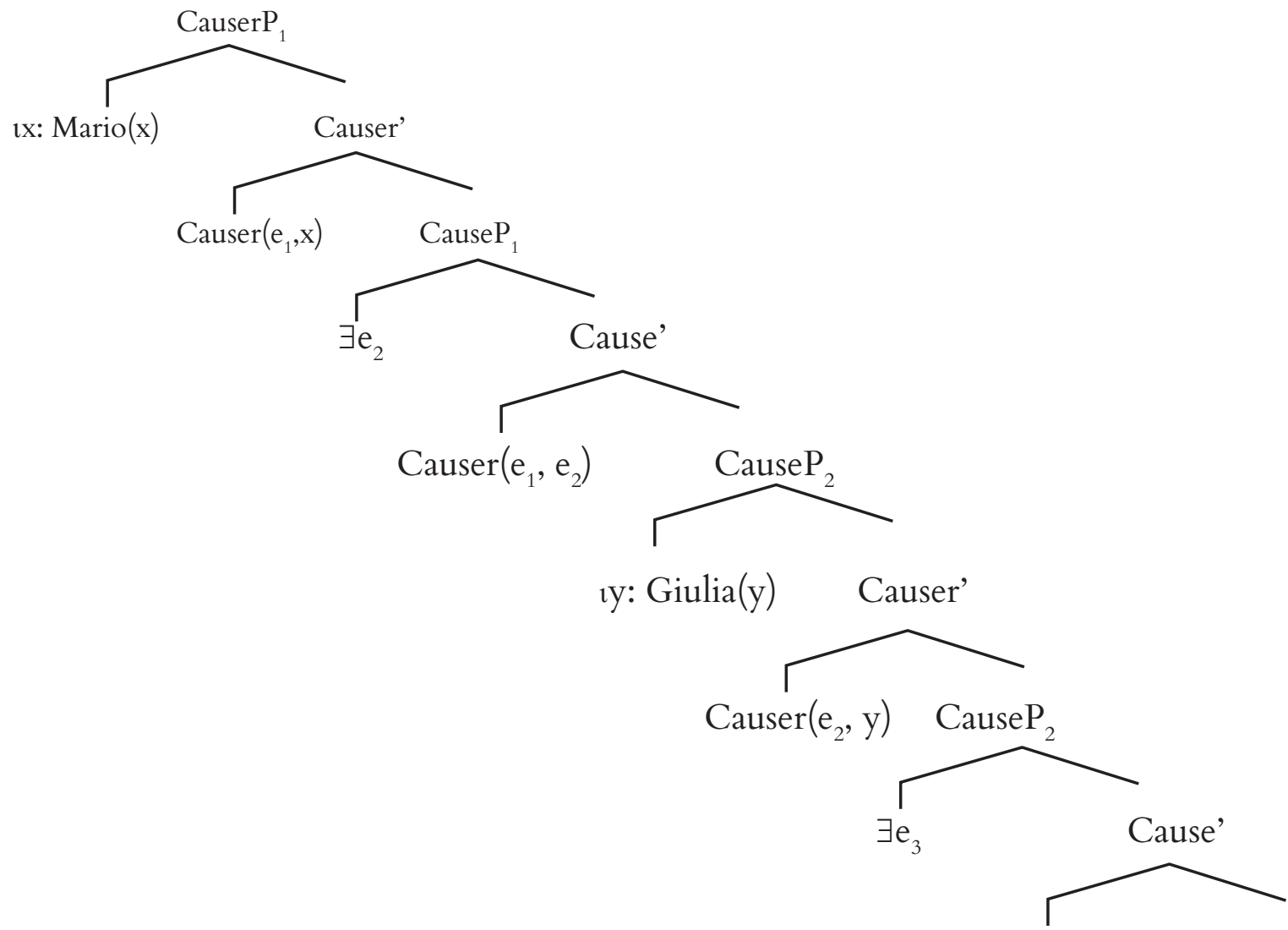

Cause(e2, e3) ThemeP

The parallel interpretation of FP and FI suggests, contra Folli and Harley (2007), that in FP as well the embedded event is realized by a complex vP. I submit that in this case the infinitive in FP is headed by a passive VoiceP that embeds a vP with an unsaturated External Argument (BRUENING, 2013). For the purpose of this paper, Ifollow recent proposals that treat passivization as carried out by a dedicated functional head (called VoicePass by Alexiadou et al. (2013)). VoicePass binds existentially the external argument of vP (29).

(29) a. [VoiceP VoicePass [VoiceP Voice [ $v P$ open the door]]]

$$
[[\text { VoicePass }]]=\lambda \mathrm{P} \lambda \mathrm{e} \exists \mathrm{x} \cdot \mathrm{P}(\mathrm{x}, \mathrm{e}) \& \operatorname{Agent}(\mathrm{x}, \mathrm{P})
$$

As a consequence, the causative structure of the FP in (30a) would be represented as in (30b), where a second causative event is still introduced in the structure, but its initiator (i.e. the Causee) is represented by a variable that is existentially bound.

(30) a. Mario ha fatto aprire la porta (da Giulia).

b. $\exists \mathrm{e} 1 \exists \mathrm{e} 2 \exists \mathrm{e} 3 \exists \mathrm{y}$. Causer(e1,Mario) \& CAUSE(e1,e2) \& Causer $(\mathrm{e} 2, \mathrm{y})$ \&

CAUSE(e2,e3) \& open(e3) \& Theme((e3,the.door) 


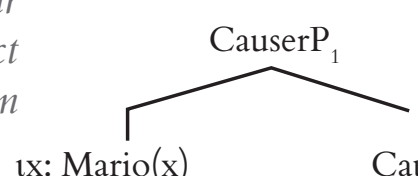

ix: $\operatorname{Mario}(\mathrm{x})$

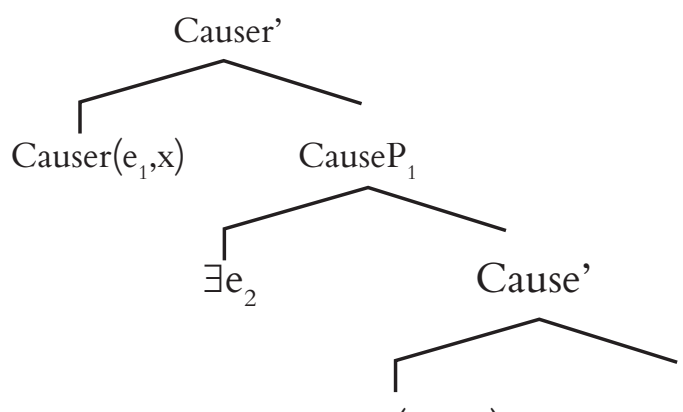

Causer $\left(\mathrm{e}_{1}, \mathrm{e}_{2}\right)$
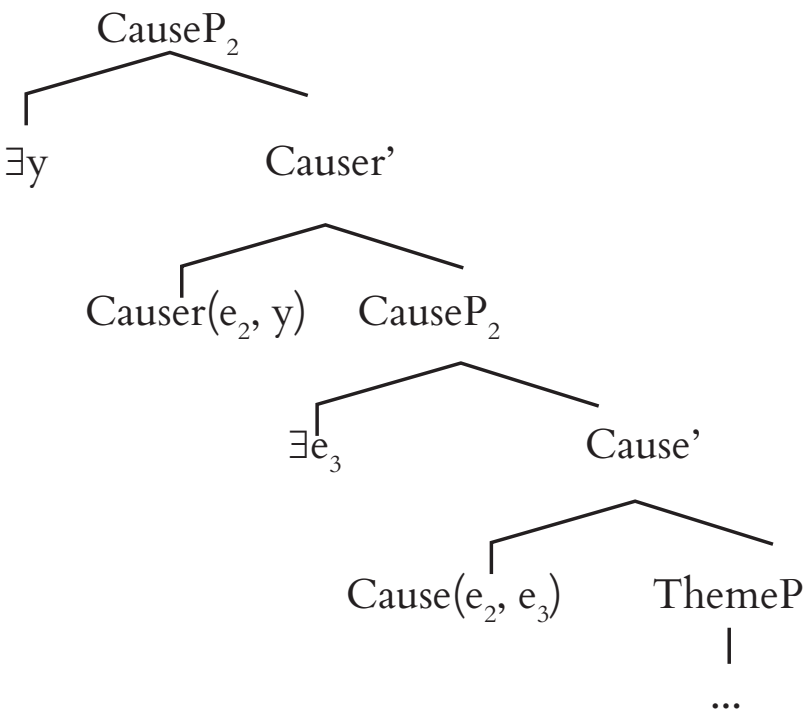

According to (30), the embedded event in FP is thus not structurally agentless, and in our view this accounts for the interpretation of the construction as an instance of indirect causation. The external argument of the embedded infinitive is introduced by a variable in FP; being already bound by the existential operator, however, this variable cannot be further co-indexed with the matrix subject (WILLIAMS, 1981).

Note that the hypothesis of a Voice head has been proposed also for explaining transitive/anticausative alternations of the type discussed in example (26c). Donazzan (2017) accounts for (26c) by following the analysis proposed by (ALEXIADOU et al., 2006), which assumes that anticausative alternations imply the suppression of the external argument position from the structure while the verb retains its CAUSE component. It is expected then that only causative predicates such as open in (26), but not activity predicates such as water in (27), can be interpreted as instances of causative chains undergoing the alternation. Also, this analysis predicts that the caused event $e_{2}$ is still controlled indirectly by the matrix subject, but at the same time, as in matrix anticausatives, the underlying causative structure realized by (26) would also license the expression of a causal modifier, optionally introduced by the "with" phrase, within the embedded clause. 


\subsubsection{Accounting for agentivity constraints}

Our analysis relying on voice alternation has the advantage to offer a framework where to incorporate the thematic constraints that we discussed in section 3.1.

In a framework where semantic and thematic information constrain the realization of argument structure, the valency change realized by Passive Voice in (29) is interpreted as the demotion of an argument. Under this view, in (29) Passive Voice is expected to bind existentially the prototypical agentive subject, i.e. the argument that, in the active sentence, is ranked higher in a hierarchy of grammatical categories based on their semantic roles (see e.g. KIPARSKY, 2013). Indeed, in Italian as in many other languages, when left implicit, the Causer in a passive construction is by default interpreted as highly agentive, i.e. prototypically human (31a), although this interpretation can be overruled by the explicit by-phrase (31b).

(31) a. Il manifestante è stato ucciso.

The protester has been killed.

Il manifestante è stato ucciso da una pallottola vagante.

The protester has been killed by a stray bullet.

The view that the application of Passive voice is driven by thematic information can be useful for understanding the generalization concerning the semantic roles of Causer and Causee in syntactic causatives that we sketched in Table 1. Remember that FP and FI end up being reanalyzed as monoclausal predicative constructions, which means that, as for the mapping to argument structure, two Causers are both presented as responsible for the realization of one final event. In the perspective of complex clause formation, passivization in the complement clause can therefore be seen as a strategy to deal with potentially conflicting information. It should apply when the first Causer is agentive, and hence the demotion of an agentive Causee, and the passivization of the complement clause, is motivated by the necessity to avoid a structure where two participants are equally ranked in terms of agentivity, i.e. are equally plausible as Causers. This hypothesis yields the correct descriptive result: according to the generalization in Table 1, FP causatives are the passive version of FI structures, where the Causer is necessarily agentive.

Nevertheless, one should remind that, as for passivization in general, the rule is not strict. It can happen that the Causee is characterized explicitly as nonagentive by the adjunct clause, as in (11a), reproduced here as (32); conversely, 
M. Donazzan Italian causatives and the grammar of indirect causation

both Causee and Causer can be agentive, as in (10b) (=33), and yet passivization does not necessarily apply.

(32) I pescatori hanno fatto spingere le barche a riva (dalla marea) the fishermen make.PF pull.INF the boats to shore da-DET tide The fishermen had the boats pulled ashore (by the tide).

(33) Il padrone ha fatto vendere la terra all' amministratore. The proprietor make.PF sell.INF the land a-DET administrator The proprietor made the administrator sell the land.

The proposed explanation however makes the right prediction if we look at FI and FP where the second event is realized by a predicate that may assign either an agentive or a non-agentive role to its subject. The correlation between FI/FP (and $a$ - vs. da-PP) and interpretive constraints has long been noted in the literature for verbs such as vedere, which is interpreted as "see" in FI vs. "visit/check" in FP, cf. (34) (MARCANTONIO, 1981).

(34) a. Mario ha fatto vedere il calcolo al/dal professore. Mario make.PF see.INF the computation a-/da-DET professor

a. Mario showed the computation to the professor FI

b. Mario had the computation checked by the professor FP

Given the hypothesis expounded above, we may suppose that passivization occurs only when the embedded predicate receives a semantically transitive interpretation, i.e. when its subject is an agentive Causer that, becoming the Causee in the causative chain, is potentially demoted in the complex predication. In fact, $(35 b)$ is better interpreted as a structure where da-PP introduces the demoted agentive Causer, i.e. as describing a situation where the pediatrician is actively examining the child, and not a mere experiencer as the subject of vedere in (32a).
a. Mario ha fatto
vedere le foto
a/??da tutti.
Mario make.PF see.INF the pictures a/da all
Mario showed the pictures to everybody.
b. Mario ha fatto vedere il bambino ??al/dal pediatra
Mario make.PF see.INF the baby a-/da-DET pediatrician
Mario made the pediatrician visit the baby.

Revista Letras,

Curitiba, UfPR, n. 96, pp.398-422, jul./dez. 2017. ISSN 2236-0999 (versão eletrônica) 
Note that the interpretation of (34) and (35) is not captured by a mere descriptive generalization such as the one in Table 1, by which the Causee of FI should be Agentive. The case of Experience Subject verb shows then that the syntactic realization of causative structures is not determined by strict lexical and selectional choices, but should rather be considered as constrained by the semantic principles that underlie Voice alternation in general, which may yield different outputs in specific linguistic contexts.

\section{Conclusions}

In this paper, I presented new evidence for treating syntactic causative constructions as the realization of a structure expressing a type of indirect causative relation. I discussed in particular the case of Italian, where syntactic causatives realize monoclausal structures, and I argued that the different structures representing complex causatives in Italian obey to the semantic constraints that determine the mapping of semantic roles into thematic positions. This account suggests that, in the frame of complex predicate formation, Voice alternations in the embedded clause in Italian are justified in order to obtain a coherent mapping between argument realization and semantic structure. The explicative power of the proposed analysis goes in this sense beyond that of previous accounts. Folli and Harley (2007) analysis, in particular, states that the FP/FI distinction is due to a difference in the semantics of the first inflected verb, which in FP is an

420 activity verb (a vDO), and ultimately predicts that FP realize instances of direct causation, a fact that, as I have shown, goes against empirical evidence. 
M. Donazzan Italian causatives and the grammar of indirect causation

\section{References}

ALEXIADOU, A.; ANAGNOSTOPOULOU, E.; SCHÄFER, F. The properties of anticausatives crosslinguistically. In FRASCARELLI, M. (Org.) Phases of interpretation. Berlin: Mouton, 2006.

ALSINA, A. A theory of complex predicates: evidence from causatives in Bantu and Romance. In: ALSINA, A.; BRESNAN, J.; SELLS, P. (Ed.). Complex predicates. Stanford: CSLI Publications, 1997. p. 203-246.

BAKER, M. Incorporation: A Theory of Grammatical Function Changing. Chicago: UoC Press, 1988.

BRUENING, B. By-phrases in passives and nominalizations. Syntax 16, p. 1-41, 2013.

BUTT, M. The structure of complex predicates in Urdu. Stanford: CSLI Publications, 1995.

DONAZZAN, M. Embedding anticausatives in Italian: evidence for Voice. Hand-out of the talk presented at CAMBRIDGE WORKSHOP ON VOICE, Cambridge University, 22-24 may, 2017.

DOWTY, D. Word meaning and Montague grammar. Dordrecht: Foris, 1991

FOLLI, R.; HARLEY, H. Causation, obligation, and argument structure: On the nature of little v. Linguistic Inquiry 38(2), 2007. p. 197-238.

FOLLI, R.; HARLEY, H. Teleology and animacy in external arguments. Lingua 118, 2008. p. 190-202.

GAETA, L. Quando i verbi compaiono come nomi. Milano: Franco Angeli, 2002.

GIVON, T. Syntax: a Functional-typological Introduction. Amsterdam: John Benjamins, 1984.

GUASTI, M.T. Restrictions in Romance causatives and the incorporation approach. Linguistic Inquiry 27(2), 1996. p. 294-313.

HALE, K.; KAYSER, S. J. On argument structure and the lexical expression of syntactic relations. In: The view from building 20, 1993. p. 53-109.

HARLEY, H. Subjects, events and licensing. Ph.D. dissertation, MIT, 1995.

KAYNE, R. French Syntax: The transformational cycle. Cambridge: MIT Press, 1975.

KIPARSKY, P. Towards a null theory of the passive. Lingua 125, 2013. p. 7-33.

KULIKOV, L; MALCHUKOV, A.; DE SWART, P. (Orgs.) Case, Valency
Revista Letras,

Curitiba, UFPR, n. 96 , pp.398-422,

jul./dez. 2017. ISSN 2236-0999 (versão eletrônica) 
and Transitivity. Amsterdam: John Benjamins, 2006.

MANZINI, M. R. Restructuring and reanalysis. Ph.D. dissertation, Cambridge, MIT, 1983.

MARCANTONIO, A. The distribution of a and da in Italian causative constructions. Journal of Italian Linguistics 6, 1981. p. 1-33

RAPPAPORT-HOVAV, M.; LEVIN, B. Building verb meanings. In: BUTT, M.; GEUDER, W. (Orgs.) The Projection of Arguments: Lexical and Compositional Factors. CLSI Publications, 1998. p. 97-134.

REINHART, T. The Theta System: An Overview. Theoretical Linguistics 28 (3), 2002. p. 229-290.

RIZZI, L. Ristrutturazione. Rivista di Grammatica Generativa 1 (1), 1976. p. $1-54$.

ROSEN, S. Argument structure and complex predicates. Ph. D. thesis, Brandeis University, 1989.

TOVENA, L; DONAZZAN, M. Italian nouns ending in -ata and the nomen vicis interpretation. Journal of Italian Linguistics. In press.

VECCHIATO, A. Events in the grammar of direct and indirect causation. Ph.D. thesis, University of Southern California, 2011.

VON STECHOW, A. The different readings of German wieder (again): a structural account. Journal of Semantics, 1996.

WILLIAMS, E. Argument structure and morphology. The Linguistic Review 1, 1981. p. 81-114.

WOLFF, P. Direct causation in the linguistic coding and individuation of causal events. Cognition 88(1), 2003.

Submetido em: 01-03-2017

Aceito em: 15-06-2017 